\title{
Effects of dexamethasone and colostrum intake on the somatotropic axis in neonatal calves
}

\author{
Stephanie N. Sauter, ${ }^{1}$ Edgar Ontsouka, ${ }^{1}$ Bettina Roffler, ${ }^{1}$ \\ Yolande Zbinden, ${ }^{1}$ Chantal Philipona, ${ }^{1}$ Michael Pfaffl, ${ }^{2}$ \\ Bernhard H. Breier, ${ }^{3}$ Jürg W. Blum, ${ }^{1}$ and Harald M. Hammon ${ }^{1}$ \\ ${ }^{1}$ Division of Animal Nutrition and Physiology, Faculty of Veterinary Medicine, Institute of Animal \\ Genetics, Nutrition, and Housing, University of Berne, CH-3012 Berne, Switzerland; ${ }^{2}$ Centre of Life \\ and Food Sciences, Institute of Physiology, Weihenstephan, Technical University of Munich, \\ D-85354 Freising-Weihenstephan, Germany; and ${ }^{3}$ Department of Pediatrics, Research Centre \\ for Developmental Medicine and Biology, University of Auckland, NZ-92019 Auckland, New Zealand
} Submitted 19 December 2002; accepted in final form 28 March 2003

\begin{abstract}
Sauter, Stephanie N., Edgar Ontsouka, Bettina Roffler, Yolande Zbinden, Chantal Philipona, Michael Pfaffl, Bernhard H. Breier, Jürg W. Blum, and Harald M. Hammon. Effects of dexamethasone and colostrum intake on the somatotropic axis in neonatal calves. Am J Physiol Endocrinol Metab 285: E252-E261, 2003. First published April 1, 2003; 10.1152/ajpendo.00557.2002.-Glucocorticoids and colostrum feeding influence postnatal maturation of the somatotropic axis. We have tested the hypothesis that dexamethasone (Dexa) affects the somatotropic axis in neonatal calves dependent on colostrum intake. Calves were fed either with colostrum or with a milk-based formula ( $n=$ 14/group), and, in each feeding group, one-half of the calves were treated with Dexa $\left(30 \mu \mathrm{g} \cdot \mathrm{kg}\right.$ body $\left.\mathrm{wt}^{-1} \cdot \mathrm{day}^{-1}\right)$. Preand postprandial blood samples were taken on days 1, 2, 4, and 5 , and liver samples were taken on day 5 of life. Dexa increased insulin-like growth factor (IGF)-I, but decreased growth hormone $(\mathrm{GH})$ and IGF-binding protein (IGFBP)-1 and -2 plasma concentrations and increased $\mathrm{GH}$ receptor (GHR) mRNA levels in liver. Dexa increased IGF-I mRNA levels only in formula-fed calves and increased hepatic GHR binding capacity, but only in colostrum-fed calves. Colostrum feeding decreased IGFBP-1 and -2 plasma concentrations and hepatic IGFBP-2 and -3 mRNA levels. In conclusion, Dexa and colostrum feeding promoted maturation of the somatotropic axis. Dexa effects partly depended on whether colostrum was fed or not.
\end{abstract}

glucocorticoids; growth hormone; growth hormone receptor; insulin-like growth factor I; insulin-like growth factor-binding proteins

THE SOMATOTROPIC AXIS is the main endocrine system regulating postnatal growth in mammals, but prenatal growth is rather independent of growth hormone $(\mathrm{GH}$; see Refs. 7 and 16). Glucocorticoids are supposed to enhance the maturation of the somatotropic axis around birth in ruminants and pigs. The prepartum cortisol surge may play an important role in initiating the perinatal switch of the somatotropic axis from the

Address for reprint requests and other correspondence: H. M. Hammon, Div. of Animal Nutrition and Physiology, Univ. of Berne, Route de la Tioleyre 4, CH-1725 Posieux, Switzerland (E-mail: harald.hammon@itz.unibe.ch). fetal to the postnatal status and function $(7,11,19)$. Cortisol stimulates hepatic GH receptor (GHR) and insulin-like growth factor I (IGF-I) mRNA levels in the sheep fetus (30), and dexamethasone (Dexa) increases hepatic GHR mRNA levels in rabbits (24). Studies with hepatocytes indicate an increase of GHR and IGF-I expression and enhanced IGF-I response to GH after Dexa administration (5). In neonatal pigs, Dexa treatment increases postnatal growth and stimulates functioning of the somatotropic axis immediately after birth (10). However, findings concerning effects of glucocorticoids on the somatotropic axis are inconsistent, perhaps because of different species or age $(9,38)$. Cortisol reduces the prenatal growth rate in sheep fetus during late gestation (17), and glucocorticoids inhibit postnatal growth, in part, by direct interaction with the somatotropic axis $(9,48,49)$. Obviously, the gestational stage and the time around birth modify glucocorticoid effects on the somatotropic axis. Therefore, one could speculate that glucocorticoids stimulate the functioning of the somatotropic axis in the neonatal calf at birth.

Several studies have recently shown that the somatotropic axis in neonatal calves works in principle and is influenced by colostrum feeding, nutrient density, and age $(13,20,47)$. Although colostral IGF-I did not affect systemic IGF-I levels in a significant manner, colostrum intake increased IGF-I plasma concentrations and hepatic IGF-I expression in neonatal calves, whereas GH plasma concentrations behaved inconsistently with respect to colostrum feeding $(13,20,23,50)$. Besides the large nutrient supply by colostrum feeding, nonnutritive components of colostrum seem to affect the IGF-I status in neonatal calves (13).

There is minor knowledge in precocious species like cattle about effects of glucocorticoids on the somatotropic axis at birth and about interactions of glucocorticoid effects with colostrum feeding. We have found

The costs of publication of this article were defrayed in part by the payment of page charges. The article must therefore be hereby marked "advertisement" in accordance with 18 U.S.C. Section 1734 solely to indicate this fact. 
high endogenous cortisol levels around birth in calves $(21,42)$. Furthermore, glucocorticoids influenced the somatotropic axis in newborn sheep and pigs $(10,30)$. On the basis of these premises, we administered Dexa to colostrum- and formula-fed neonatal calves, starting the treatment immediately after birth to simulate a high glucocorticoid status. The objective of this study was to clarify the effects of glucocorticoids on the somatotropic axis and whether these effects depend on feeding colostrum or milk-based formulas that contained nutrients in similar amounts to colostrum, but much fewer growth-promoting substances like hormones and growth factors $(3,42)$. We have tested the hypothesis that Dexa influences the maturation of the somatotropic axis in neonatal calves and that Dexa effects are modified by colostrum feeding. Therefore, we have measured various components of the somatotropic axis in blood and mRNA concentrations in liver as well as GHR binding sites in liver.

\section{MATERIALS AND METHODS}

Animals, husbandry, feeding, and experimental procedures. The experimental procedures were approved by the Cantonal Committee for the Permission of Animal Experimentation (Granges-Paccot, Canton of Fribourg, Switzerland) and followed the actual law of animal protection. They were supervised by the Federal Veterinary Administration. Twenty-eight male calves (11 Holstein-Friesian, 12 Simmental $\times$ Red Holstein, 4 Brown Swiss, and 1 Red Holstein $\times$ Limousin) were studied. They were born at the Federal Research Station for Animal Production (Posieux, Switzerland) or at neighboring farms. Calves were born spontaneously and were separated immediately after birth from their dams and held on straw in boxes for 5 days.

Four treatment groups were created randomly $\left(\mathrm{GrFD}^{-}\right.$, $\mathrm{GrFD}^{+}, \mathrm{GrCD}^{-}, \mathrm{GrCD}^{+}$), each consisting of seven calves (Table 1). Calves of $\mathrm{GrCD}^{-}$and $\mathrm{GrCD}^{+}$received colostrum of milkings 1,3 , and 5 (days 1, 2, and 3 after parturition, respectively) on the first 3 days. Calves of $\mathrm{GrFD}^{-}$and $\mathrm{GrFD}^{+}$ were fed three different milk-based formulas for days 1, 2, and 3 that represented colostral milkings 1,3 , and 5, respectively. Calves of $\mathrm{GrCD}^{+}$and $\mathrm{GrFD}^{+}$were treated with 30 $\mu \mathrm{g} \cdot \mathrm{kg}$ body wt ${ }^{-1} \cdot$ day $^{-1}$ Dexa (Dexa TAD; Lohmann Animal Health, Cuxhaven, Germany). Calves were primarily grouped with the goal to obtain similar body weight and breed distributions in all four groups. Calves were fed by bottle two times daily. To ensure that all calves received the same amounts of formula or colostrum, calves with reduced appetite were tube fed their planned amounts of formula or colostrum. Calves received their first meal at $3.1 \pm 0.04 \mathrm{~h}$ $\left(\mathrm{GrFD}^{-}\right), 2.2 \pm 0.02 \mathrm{~h}\left(\mathrm{GrFD}^{+}\right), 2.4 \pm 0.03 \mathrm{~h}\left(\mathrm{GrCD}^{-}\right)$, and $3.4 \pm 0.04 \mathrm{~h}\left(\mathrm{GrCD}^{+}\right)$after birth. The following feedings were at 8,24 , and $32 \mathrm{~h}$ after the first feeding. From day 3 on, calves were fed daily at 0800 and at 1600 .

Colostrum was from cows of the Federal Research Station for Animal Production. Cows were milked two times daily, and the colostrums of milkings 1 (day 1), 3 (day 2), and 5 (day 3) after parturition were stored separately in plastic bottles at $-20^{\circ} \mathrm{C}$. Individual pools of milkings 1,3 , and 5 were prepared at the beginning of the study and then stored in plastic bottles at $-20^{\circ} \mathrm{C}$ until used. Before feeding, colostrum was warmed to $40^{\circ} \mathrm{C}$ and then fed immediately.

Three formulas for days 1,2, and 3 were created that contained nutrients (protein, fat, lactose) in comparable amounts as colostrum milkings 1, 3, and 5 after parturition and were fed on days 1, 2, and 3 after birth. Formulas were produced by UFA (Sursee, Switzerland) and consisted of calcium-caseinate (Emmi Milch, Lucerne, Switzerland), lactalbumin (Emmi Milch), milk fat (double cream; Institut Agricole de l'Etat de Fribourg, Grangeneuve, Switzerland), and a vitamin and mineral premix (Provimi, Cossonay-Gare, Switzerland). The three formulas were dissolved by adding water and were stored in plastic bottles at $-20^{\circ} \mathrm{C}$ until used. Before feeding, formulas were warmed to $40^{\circ} \mathrm{C}$ and then fed immediately. The milk replacer (UFA 200 natura, without antibiotics) was prepared as a $100 \mathrm{~g} / \mathrm{l}$ solution. Contents of different colostrum milkings, formulas, and milk replacer are shown in Table 2.

To protect against infections, all calves were subcutaneously injected with $2 \mathrm{~g}$ of a bovine colostral immunoglobulin preparation (Gammaserin; Gräub, Berne, Switzerland) before the first feed intake. Additionally, all calves were fed chicken egg-derived immunoglobulins containing high-antibody titers against rotavirus and pathogenic Escherichia coli type K 99 (Globigen 88; kindly donated by Lohmann Animal Health). Fed amounts were $10 \mathrm{~g}$ (day 1), $8 \mathrm{~g}$ (day 2), $6 \mathrm{~g}$ (day 3 ), and $4 \mathrm{~g}$ (day 4)/meal. On days 1, 2, and 3, calves were subcutaneously injected antibiotics (25 mg Enrofloxacin/10 kg body wt; 5\% Baytril; Bayer, Leverkusen, Germany). To avoid different treatment protocols, drugs were given to both formula- and colostrum-fed calves.

Health status. The health status was evaluated daily based on the following clinical traits: rectal temperature, heart rate, respiratory rate, behavior, nasal discharge, respiratory

Table 1. Experimental groups

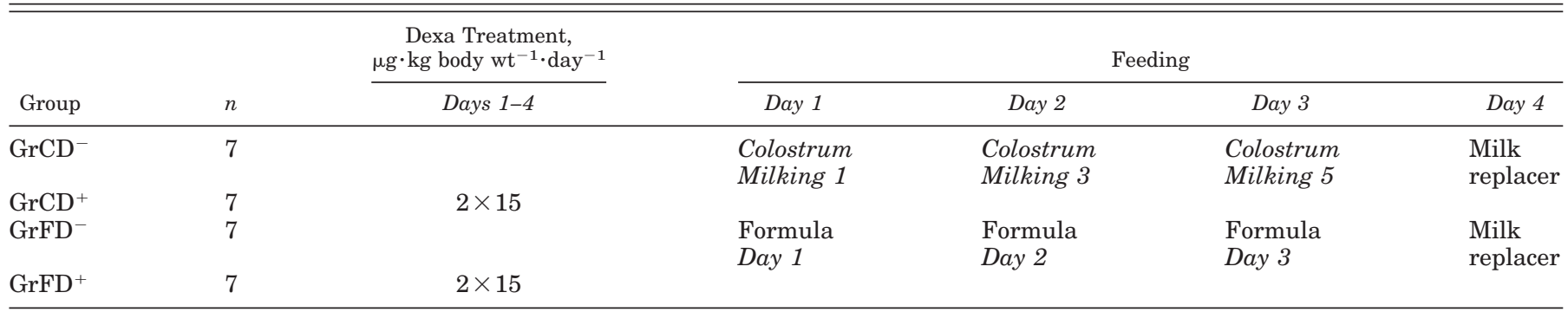

Twenty-eight calves were randomly grouped and were fed either colostrum $\left(\mathrm{GrCD}^{-}\right.$and $\left.\mathrm{GrCD}^{+}\right)$or formula $\left(\mathrm{GrFD}^{-}\right.$and $\left.\mathrm{GrFD}{ }^{+}\right)$. In each feeding group, one-half of the calves were treated with dexamethasone (Dexa) $\left(\mathrm{GrCD}^{+}\right.$and $\left.\mathrm{GrFD}^{+}\right)$. With Dexa treatment, calves were treated two times daily at feeding times; dose of DEXA was chosen according to previous studies in neonatal calves (14). Day 1, colostrum and formula were fed in amounts of $6 \%$ of body wt; Day 2, colostrum and formula were fed in amounts of $8 \%$ of body wt; Days 3 and 4 , colostrum and formula were fed in amounts of $10 \%$ of body wt. 
Table 2. Composition of colostrum milkings, formula, and milk replacer fed to neonatal calves

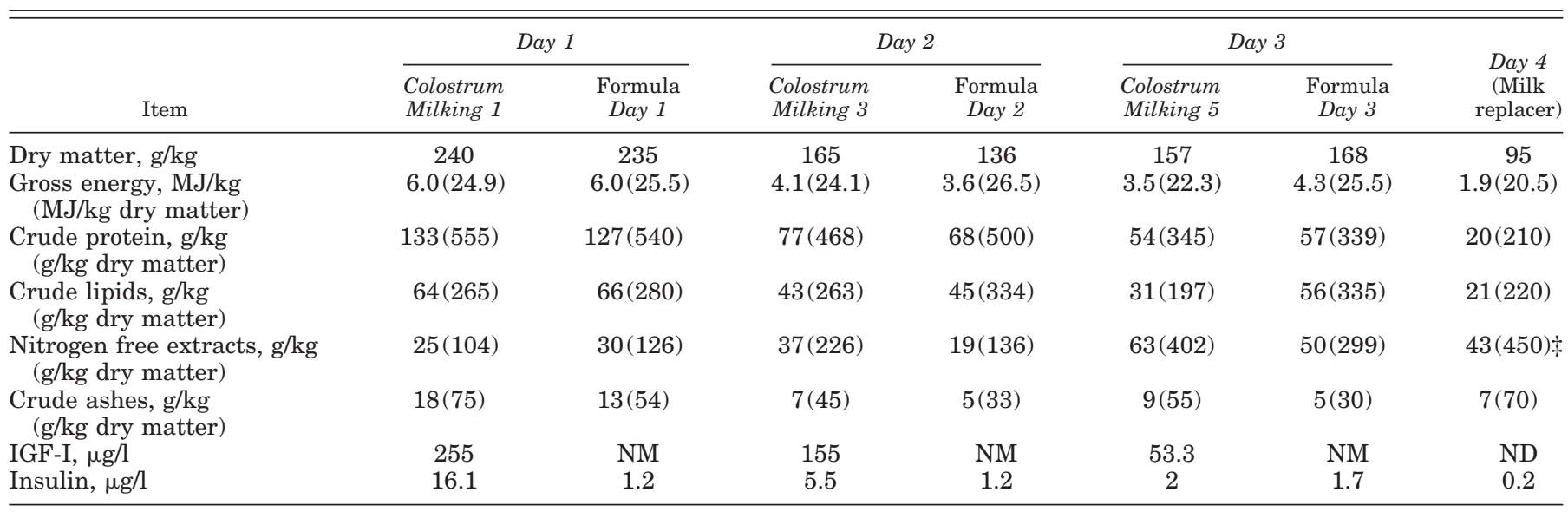

Formula (per kg) was composed of calcium-caseinate $(86,208$, and $282 \mathrm{~g}$ on days 1,2 , and 3 , respectively), lactalbumin (576, 245, and 80 g on days 1, 2, and 3, respectively), milk fat (267, 262, and $353 \mathrm{~g}$ double cream on days 1, 2, and 3, respectively), lactose (57, 271, and 271 $\mathrm{g}$ on days 1, 2, and 3, respectively), and a mineral premix (14 g on days 1-3). The mineral premix (per kg) contained calcium (186 g), magnesium (224 g), sodium (31 g), phosphorus (92 g), chlorine (48 g), iron (12 g), manganese (8.1 mg), copper (1.6 mg), zinc (7.8 mg), iodine $(0.03 \mathrm{mg})$, cobalt $(0.02 \mathrm{mg})$, and selenium $(0.02 \mathrm{mg})$. Milk replacer was fed as $10 \%$ solution (wt/vol) and was composed (per kg) of skim milk powder (550 g), whey (40 g), corn-derived products (dextrose, glucose, oat cream, starch; $172 \mathrm{~g}$ ), tallow (145 g), lard (44 g/kg), lecithin (as emulgator; $19 \mathrm{~g}$ ), calcium (12 g), phosphorus (7.5 g), magnesium (1.6 g), sodium (4.9 g), zinc (80 mg), manganese (60 mg), iron (20 mg), copper

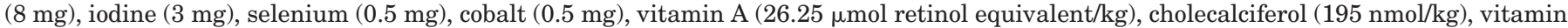
$\mathrm{E}\left(360 \mu \mathrm{mol} \alpha\right.$-tocopherol $/ \mathrm{kg}$;), thiamine $(57 \mu \mathrm{mol} / \mathrm{kg})$, riboflavin $(21 \mu \mathrm{mol} / \mathrm{kg})$, vitamin $\mathrm{B}_{6}(59 \mu \mathrm{mol} / \mathrm{kg})$, and vitamin $\mathrm{B}_{12}(37 \mathrm{nmol} / \mathrm{kg})$. Milk replacer included $30 \mathrm{~g}$ lactose/kg milk (320 g/kg dry matter). NM, not measurable (below detection limit). ND, not determined.

sounds, appetite, fecal consistency, and navel adspection. Body weight was determined on days 1 and 5 of life.

Blood samples. Blood samples were taken from the jugular vein with evacuated tubes on days 1,2 , and 5 and with a catheter on day 4. Tubes containing dipotassium-EDTA (1.8 $\mathrm{g} / \mathrm{l}$ blood) were used for the determination of pre- and postprandial values of IGF-I and IGF-binding protein (IGFBP)-1 at $0,1,2,4$, and $8 \mathrm{~h}$ after the $1 \mathrm{st}$, 3rd, and 7 th feeding and on day 5 and for the determination of preprandial values of IGFBP-2 and IGFBP-3 on days 1 and 4, respectively. The same tubes were used to measure plasma concentrations of $\mathrm{GH}$ in pre- and postprandial samples on days 1 and 2 , in 25 samples on day 4 taken before $(0 \mathrm{~h})$ and every 20 min after the morning feeding for $8 \mathrm{~h}$ for the evaluation of secretory patterns, and on day 5. Tubes were put on crushed ice and centrifuged at $1,000 \mathrm{~g}$ for $20 \mathrm{~min}$. Supernatants were separated into aliquots and stored at $-20^{\circ} \mathrm{C}$.

Blood analyses. Plasma GH, IGF-I, and IGFBP-1 concentrations were measured by RIA, as described previously (20, 26). Plasma concentrations of IGFBP-2 and IGFBP-3 were measured by ligand blots using ${ }^{125} \mathrm{I}$-labeled IGF-I. The procedure was described recently $(20,23)$.

Analyses in liver. Calves were slaughtered on day 5 of life, and liver samples were put either in liquid nitrogen (GHR binding studies) or in TRIzol (GIBCO-BRL, Basel, Switzerland) and then frozen in liquid nitrogen. Liver samples were stored at $-80^{\circ} \mathrm{C}$ until analyzed for mRNA of IGF-I, IGF-II, IGFBP-2, IGFBP-3, and GHR and for GHR binding sites.

For mRNA measurements, total RNA was extracted using TRIzol reagent (GIBCO-BRL) and resuspended in RNasefree water that was treated with diethyl pyrocarbonate (Sigma-Aldrich, Deisendorf, Germany). RNA integrity and purity were tested by measurement of optical density and by electrophoresis using ethidium bromide staining. Total RNA was reverse transcribed into cDNA with hexamer primers (Pharmacia Biotech, Buckinghamshire, UK), as described previously (40). Materials and procedures for RT-PCR, including primers for bovine IGF-I, IGF-II, IGFBP-2, IGFBP-3, and GHR mRNA, were recently described in detail $(18,40)$. RT-PCR quantification was performed with the LightCycler system (Roche Molecular Biochemicals, Rotkreuz, Switzerland), using the software package 3.3 (Roche Molecular Biochemicals). Absolute quantification was based on external recombinant DNA standards (40) and was related to $18 \mathrm{~S}$ RNA to compensate for RNA loading differences. Values were expressed on a molar basis.

For ${ }^{125} \mathrm{I}-\mathrm{GH}$-binding studies, liver samples were thawed and transferred to receptor buffer (in $\mathrm{mM}$ : 50 Tris $\cdot \mathrm{HCl}, 6$ $\mathrm{MgCl}_{2}$, and 1 EGTA; pH $7.4 ; 4^{\circ} \mathrm{C}$ ). The tissue was homogenized four times for $20 \mathrm{~s}$ at low speed $(8,000 \mathrm{U} / \mathrm{min})$ with an Ultra-Turrax homogenizer (T25; Janke \& Kunkel, Staufen, Germany). The homogenate was centrifuged at $800 \mathrm{~g}$ for 10 min, and the supernatant was centrifuged at $10,000 \mathrm{~g}$ for 10 min; thereafter, the resulting supernatant was centrifuged again at $100,000 \mathrm{~g}$ for $1 \mathrm{~h}(22)$. The remaining pellet was resuspended in ice-cold buffer (as above) by a motor-driven glass-Teflon homogenizer and stored at $-80^{\circ} \mathrm{C}$ until assayed. The protein concentration was determined using a kit (BCA Protein Assay Reagent; Pierce, Rockford, IL), and then the membrane suspensions were adjusted to a final protein concentration of $4 \mathrm{mg} / \mathrm{ml}$. For receptor measurements, membranes were suspended in incubation buffer (as above). Linearity of binding dependent on protein concentration was tested, and the final protein concentration in assays was within the linear range. Binding of ${ }^{125} \mathrm{I}$-recombinant bovine $\mathrm{GH}$ (rbGH) was measured as previously described (1, 22). The rbGH was from Monsanto (St. Louis, MO), and prolactin was from the United States Department of Agriculture Animal Hormone Program (Dr. D. Bolt, Beltsville, MD). Competitive binding studies for the characterization of ${ }^{125} \mathrm{I}-\mathrm{rbGH}$ binding sites were performed in pooled membrane suspensions with $0.35 \mathrm{ng}$ of the radiolabeled ligand and increasing concentrations of unlabeled rbGH and prolactin. For the determination of the number of ${ }^{125} \mathrm{I}-\mathrm{rbGH}$ binding sites, the radiolabeled $\mathrm{rbGH}(0.35 \mathrm{ng})$ was incubated with increasing concentrations of the unlabeled rbGH $(1,22)$. 
Analyses in formula, colostrum, and milk replacer. Samples of formulas 1,2, and 3 and samples of the individual pools of colostrum of milkings 1,3 , and 5 were lyophilized to determine dry matter, crude protein (by the Kjeldahl method), crude fat (by the Berntrop method), and ashes (after combustion at $550^{\circ} \mathrm{C}$ ) using standard procedures at the Swiss Federal Research Station for Animal Production. Contents of nitrogen-free extracts and gross energy (based on energy equivalents of $36.6,17.0$, and $24.2 \mathrm{MJ} / \mathrm{kg}$ fat, nitrogen-free extracts, and crude protein) were calculated. Information on contents of the milk replacer was given by the producer. Concentrations of insulin and IGF-I in formula and colostrum were analyzed as described by Hammon and Blum $(20,21)$.

Statistical procedures. Values of body weight, blood traits, mRNA concentrations, and GH binding sites were expressed as means $\pm \mathrm{SE}$ or pooled SE. For plasma concentrations of GH, IGF-I, and IGFBP-1, areas under the concentration curves were computed for each day as measures of mean concentrations between 0 and $8 \mathrm{~h}$. The ratios of GH to IGF-I plasma concentrations were calculated as means for describing the maturation of the GH-IGF-I system, as defined by Gluckman et al. (19). Data were evaluated using the RANDOM and REPEATED methods of the MIXED procedure (45). Separate models were applied for the calculation of body weight as well as preprandial and mean concentrations of GH, IGF-I, and IGFBPs during the whole experimental period and for the calculation of postprandial effects on days 1, 2 , and 4, respectively. Dexa treatment, feeding, and time were used as fixed effects, and the individual calves were used as random effects. For the evaluation of differences in Dexa responses with regard to different feeding and for the evaluation of differences in the time pattern within Dexa or feeding groups, interactions (Dexa $\times$ feeding; Dexa $\times$ time; feeding $\times$ time) were included in the model. Treatment, feeding, and time differences were localized by the Bonferroni $t$-test $(P<0.05)$. Episodic secretion of $\mathrm{GH}$ on day 4 (mean concentrations, basal concentrations, peak amplitudes, and peak frequencies) was analyzed according to Merriam and Wachter (36). Group differences were analyzed by the general linear model (GLM) and differences were localized by Bonferroni $t$-test $(P<0.05$; see Ref. 45$)$.

Concentrations of mRNA as well as number $\left(\mathrm{B}_{\max }\right)$ and $50 \%$ inhibition $\left(\mathrm{IC}_{50}\right)$ of $\mathrm{GH}$ binding sites were evaluated using the GLM (45) with Dexa treatment and feeding as main effects. The Dexa $\times$ feeding interaction was included in the model. Dexa treatment and feeding effects were localized by the Bonferroni $t$-test $(P<0.05)$.

\section{RESULTS}

Feed intake, body weight, and health status. Feed intake was the same in all four groups. The mean body weights of all four groups before the first meal (46.7 \pm $3.8 \mathrm{~kg}$ ) were the same and did not change until day 5 $(46.5 \pm 3.8 \mathrm{~kg})$. There were no differences in health traits among the different groups (data not shown). However, two calves of $\mathrm{GrFD}^{-}$and $\mathrm{GrFD}^{+}$had loose feces for 2 days.

Blood hormone concentrations. Preprandial plasma GH concentrations (Fig. 1) did not change from day 1 to day 5 but were higher $(P<0.05)$ before the first feed intake in Dexa-treated than in nontreated calves. Concentrations of $\mathrm{GH}$ on day 1 changed with time in an inconsistent manner but on day 2 remained low in Dexa-treated groups and transiently increased $(P<$ 0.1 ) after feed intake in nontreated groups. On day 4 , concentrations postprandially increased $(P<0.01)$ in nontreated groups, whereas GH concentrations remained low in Dexa-treated groups. Mean and basal concentrations as well as amplitudes of secretory peaks were lower $(P<0.05)$ in Dexa-treated than in nontreated groups.

Preprandial plasma concentrations of IGF-I (Fig. 2) decreased $(P<0.01)$ in nontreated calves from day 1 to day 5. Mean concentrations remained unchanged in Dexa-treated calves from day 1 to day 2 but decreased $\left(P<0.01\right.$ in $\mathrm{GrFD}^{+} ; P<0.1$ in $\left.\mathrm{GrCD}^{+}\right)$from day 2 to

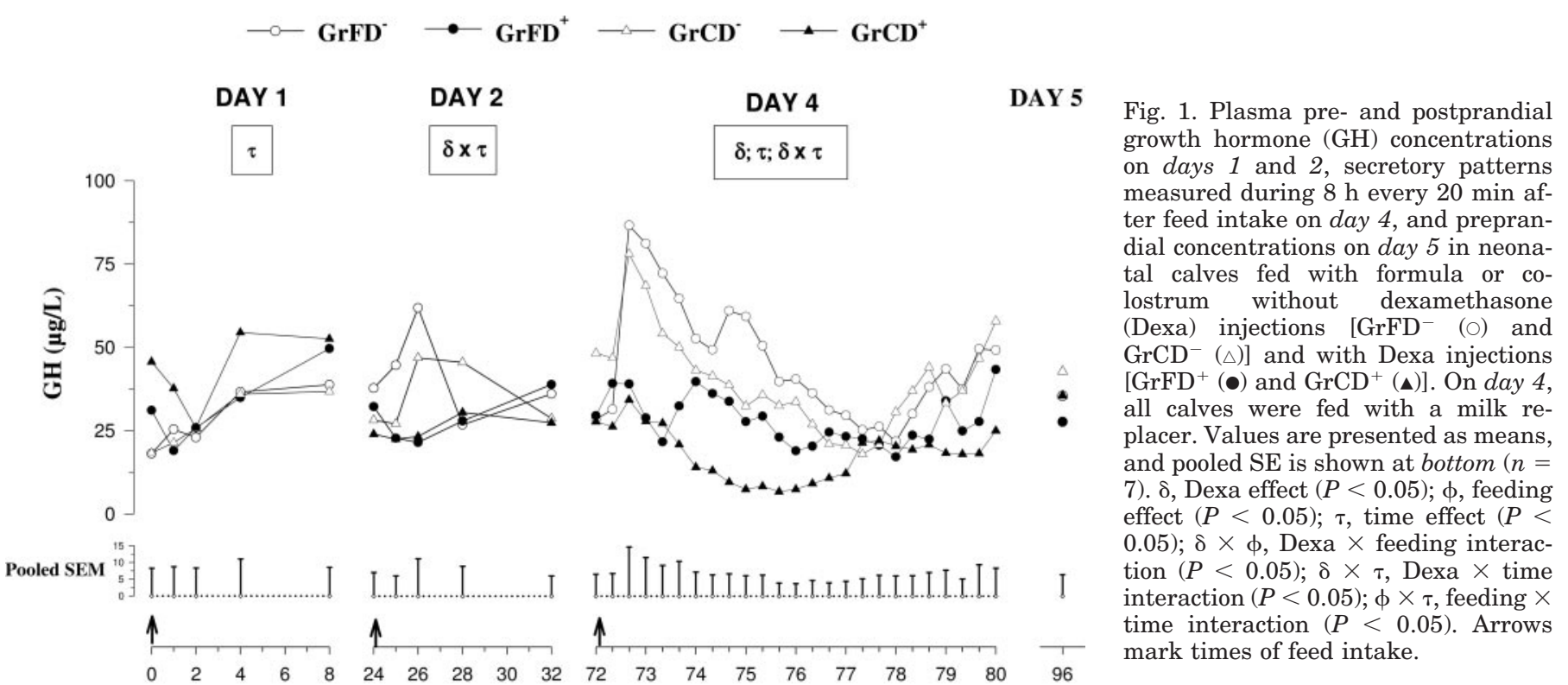

Time after first meal (h) 
Fig. 2. Plasma pre- and postprandial IGF-I concentrations on days 1,2, and 4 and preprandial concentrations on day 5 in neonatal calves fed with formula or colostrum without Dexa injections $\left[\mathrm{GrFD}^{-}(\mathrm{O})\right.$ and $\left.\mathrm{GrCD}^{-}(\triangle)\right]$ and with Dexa injections $\left[\mathrm{GrFD}^{+}(\bullet)\right.$ and $\left.\mathrm{GrCD}^{+}(\mathbf{\Delta})\right]$. On day 4, all calves were fed with a milk replacer. For further details see legend to Fig. 1.

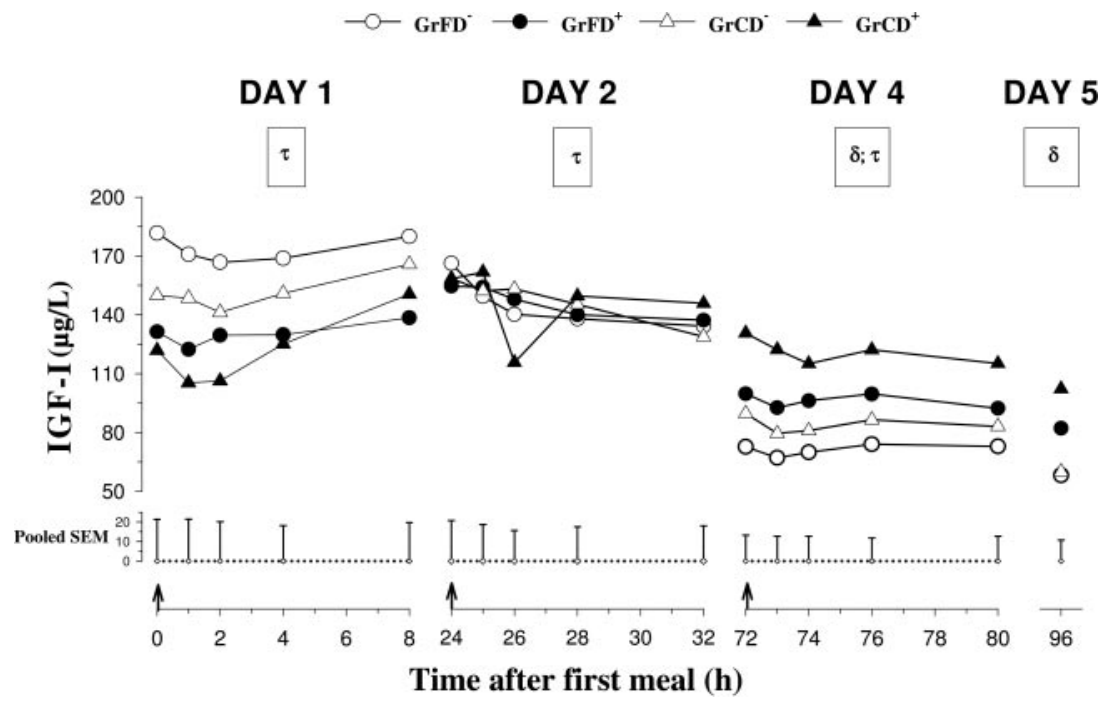

day 4. Postprandial concentrations changed $(P<0.05)$ with time after feed intake on days 1,2 , and 4 , decreased in $\mathrm{GrFD}^{-}(P<0.01)$ on day 2 , and decreased $(P<0.05)$ in colostrum-fed groups on day 4 . Preprandial IGF-I concentrations on day 1 were lower $(P<$ $0.05)$ in Dexa-treated than in nontreated calves. Dexa treatment increased $(P<0.05)$ IGF-I concentrations compared with nontreated calves on days 4 and 5 . The ratios of mean GH to mean IGF-I plasma concentrations on day 4 were lower $(P<0.001)$ in Dexa-treated than in nontreated calves and tended to be lower $(P<$ 0.1 ) in colostrum-fed than in formula-fed calves (ratios were $0.68 \pm 0.1,0.3 \pm 0.03,0.53 \pm 0.1$, and $0.14 \pm$ 0.004 for $\mathrm{GrFD}^{-}, \mathrm{GrFD}^{+}$, $\mathrm{GrCD}^{-}$, and $\mathrm{GrCD}^{+}$, respectively).

Preprandial plasma concentrations of IGFBP-1 (Fig. 3) decreased in $\mathrm{GrFD}^{+}, \mathrm{GrCD}^{-}$, and $\mathrm{GrCD}^{+}(P<0.05)$ from day 1 to day 2 and remained unchanged until day 5. Plasma concentrations decreased on day $1(P<0.05)$ after feed intake in colostrum-fed calves and responded $(P<0.05)$ to feed intake on days 2 and 4 in nontreated calves. Preprandial IGFBP-1 concentrations on day 1 were higher $(P<0.05)$ in colostrum-fed than in formula-fed calves. IGFBP-1 concentrations from day 2 to day 5 were lower $(P<0.05)$ in Dexa-treated than in nontreated calves. On days 2 and 5, IGFBP-1 concentrations tended to be higher in $\mathrm{GrFD}^{-}$than in $\mathrm{GrCD}^{-}$.

Plasma concentrations of IGFBP-2 increased $(P<$ $0.05)$ in $\mathrm{GrFD}^{-}$and decreased $(P<0.05)$ in $\mathrm{GrCD}^{+}$ from day 1 to day 4 (Table 3). Plasma concentrations of IGFBP-2 on day 4 were lower $(P<0.05)$ in Dexatreated than in nontreated calves and were lower in colostrum-fed than in formula-fed calves, and the Dexa-induced reduction was greater $(P<0.01)$ in formula-fed than in colostrum-fed calves. Plasma concentrations of IGFBP-3 decreased $(P<0.05)$ in $\mathrm{GrFD}^{-}$ from day 1 to day 4 (Table 3 ). There were no differences concerning Dexa treatment or feeding.
Fig. 3. Plasma pre- and postprandial IGF-binding protein (IGFBP)-1 concentrations on days 1,2 , and 4 and preprandial concentrations on day 5 in neonatal calves fed with formula or colostrum without Dexa injections $\left[\mathrm{GrFD}^{-}(\mathrm{O})\right.$ and $\left.\mathrm{GrCD}^{-}(\triangle)\right]$ and with Dexa injections $\left[\mathrm{GrFD}^{+}(\bullet)\right.$ and $\mathrm{GrCD}^{+}$ (₫)]. On day 4, all calves were fed with a milk replacer. For further details see legend to Fig. 1.

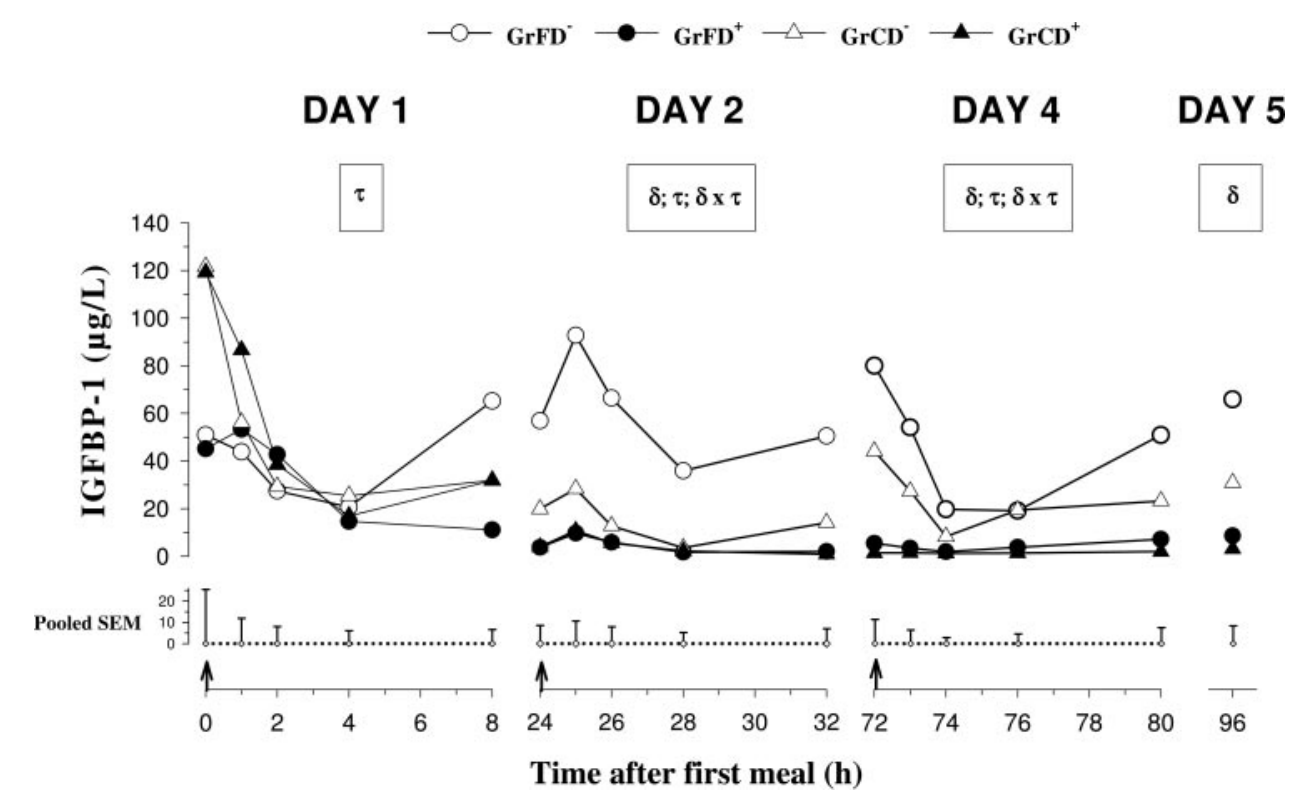

AJP-Endocrinol Metab • VOL 285 • AUGUST $2003 \bullet$ www.ajpendo.org 
Table 3. Plasma concentrations of IGFBP-2 and IGFBP-3 in newborn calves fed with formula or colostrum with $\left(\mathrm{GrFD}^{+}, \mathrm{GrCD}{ }^{+}\right)$or without Dexa injections $\left(\mathrm{GrFD}^{-}, \mathrm{GrCD}^{-}\right)$

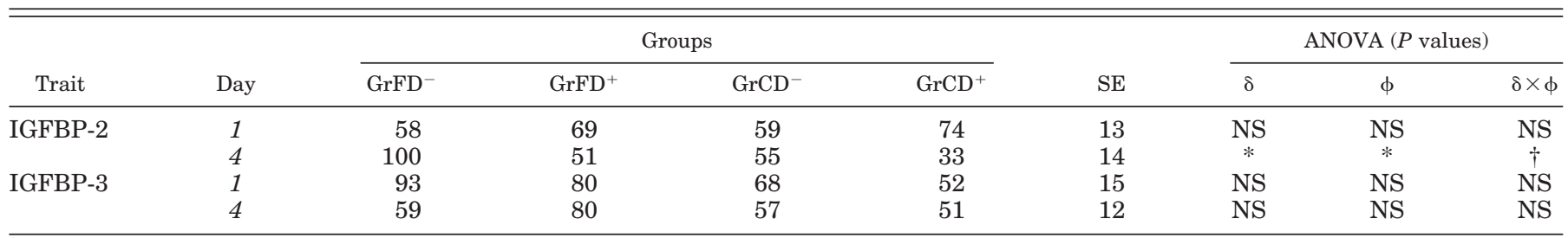

Values are means; $n=7$ animals/group. Units are optical density $\times 10^{3}$. IGFBP, IGF-binding protein; SE, pooled standard error; $\delta$, Dexa effect; $\phi$, feeding effect; $\delta \times \phi$, Dexa $\times$ feeding interaction. NS, statistically not significant. $* P<0.05$ and $\dagger P<0.01$.

Hepatic mRNA concentrations on day 5 of life. Expression of IGF-I tended to be higher $(P<0.1)$ in Dexa-treated than in nontreated calves and was higher $(P<0.05)$ in $\mathrm{GrFD}^{+}$than in $\mathrm{GrFD}^{-}$and in $\mathrm{GrCD}^{+}$ (Table 4). Expression of IGF-II tended to be higher $(P<$ 0.1 ) in formula-fed than in colostrum-fed calves. Dexa treatment resulted $(P<0.1)$ in different responses to feed intake in formula-fed and colostrum-fed calves. Expression of IGFBP-2 and IGFBP-3 was higher $(P<$ 0.001 and $P<0.01)$ in formula-fed than in colostrumfed calves. Calves treated with Dexa showed higher expression $(P<0.01)$ of GHR than nontreated calves.

Hepatic $G H$ binding sites on day 5 of life. In ${ }^{125} \mathrm{I}-\mathrm{GH}$ binding studies (Fig. $4 A$ ), $\mathrm{IC}_{50}$ of unlabeled rbGH was $4.1 \times 10^{-10} \mathrm{M}$, and $\mathrm{IC}_{50}$ of prolactin was $5.4 \times 10^{-6} \mathrm{M}$. Dexa treatment resulted in different effects on $B_{\max }$ in formula-fed and colostrum-fed calves $(P<0.1$ for Dexa $\times$ feeding interaction), and $\mathrm{B}_{\max }$ tended to be higher $(P<0.1)$ in $\mathrm{GrCD}^{+}$than in $\mathrm{GrCD}^{-}$(Fig. $4 B$ ). $\mathrm{IC}_{50}$ of $\mathrm{GH}$ binding sites were similar in different groups.

\section{DISCUSSION}

Feed intake, body weight, and health status. Decreases in dry matter, gross energy, crude protein, crude fat, crude ashes, insulin, and IGF-I concentrations but an increase in nitrogen-free extracts (mainly of lactose) in colostrum of milkings 1, 3, and 5 fed to neonatal calves have also been observed in earlier studies (42). Because formulas of days 1,2, and 3 contained similar amounts of nutrients as the colostrum of milkings 1, 3, and 5 and because on day 4 all calves received the same milk replacer, nutrient intakes were comparable in different feeding groups.
However, concentrations of biologically active factors like IGF-I or insulin were much lower in the three formulas than in colostrum and possibly affected neonatal development because receptors for IGF-I and insulin are present in the gut mucosa of neonatal calves $(18,22)$. Body weight remained stable during the experimental period, and Dexa treatment or different feeding did not affect growth performance, yet the experimental period of 5 days was too short to get reliable data on effects of Dexa on growth performance, as was the case in 18-day-old pigs (10).

Feeding and treatment effects on GH and GHR. Plasma GH concentrations in our study were not influenced by different feeding but were reduced by Dexa treatment. Plasma GH concentrations were barely regulated by feeding in neonatal calves $(20,23,42)$, whereas they were influenced by feeding intensity in older cattle $(7,43)$. Because nutrient intake was the same in the present study, nonnutritive factors such as IGFs, IGFBPs, and lactoferrin, which are present in high amounts in colostrum (3) but not in the formulas, obviously did not influence GH secretion. In cattle, plasma GH concentrations decrease during ontogenetic development $(8,14)$. Because glucocorticoids are important for neonatal maturation (7), reduced GH concentrations after Dexa treatment in our study might indicate enhanced maturation of the somatotropic axis, as shown in neonatal pigs (10). On the other hand, cortisol treatment in 1-mo-old calves did not affect plasma GH concentrations (15). Because glucocorticoids have stimulatory and inhibitory effects on pituitary GH production and release (38), effects of glucocorticoids on GH secretion may depend on the developmental status. In addition, reduced GH concen-

Table 4. Expression of IGF-I, IGF-II, IGFBP-2, IGFBP-3, and GHR on day 5 of life in liver of newborn calves fed with formula or colostrum with $\left(\mathrm{GrFD}^{+}, \mathrm{GrCD} D^{+}\right)$or without Dexa injections $\left(G r F D^{-}, \mathrm{GrCD}^{-}\right)$

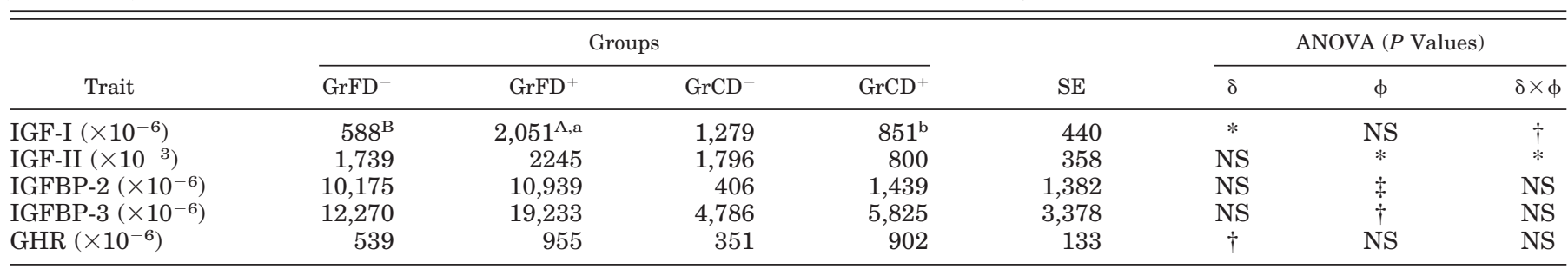

Values are means; $\mathrm{n}=7$ animals/group. Units are fmol/g total RNA. GHR, growth hormone receptor NS, statistically not significant. $* P<$ $0.1, \dagger P<0.01$, and $\ddagger P<0.001$. Means with different capital letter superscripts (A, B) are significantly different $(P<0.05)$ within Dexa treatment; means with different small letter superscripts $(a, b)$ are significantly different $(P<0.05)$ within feeding. 

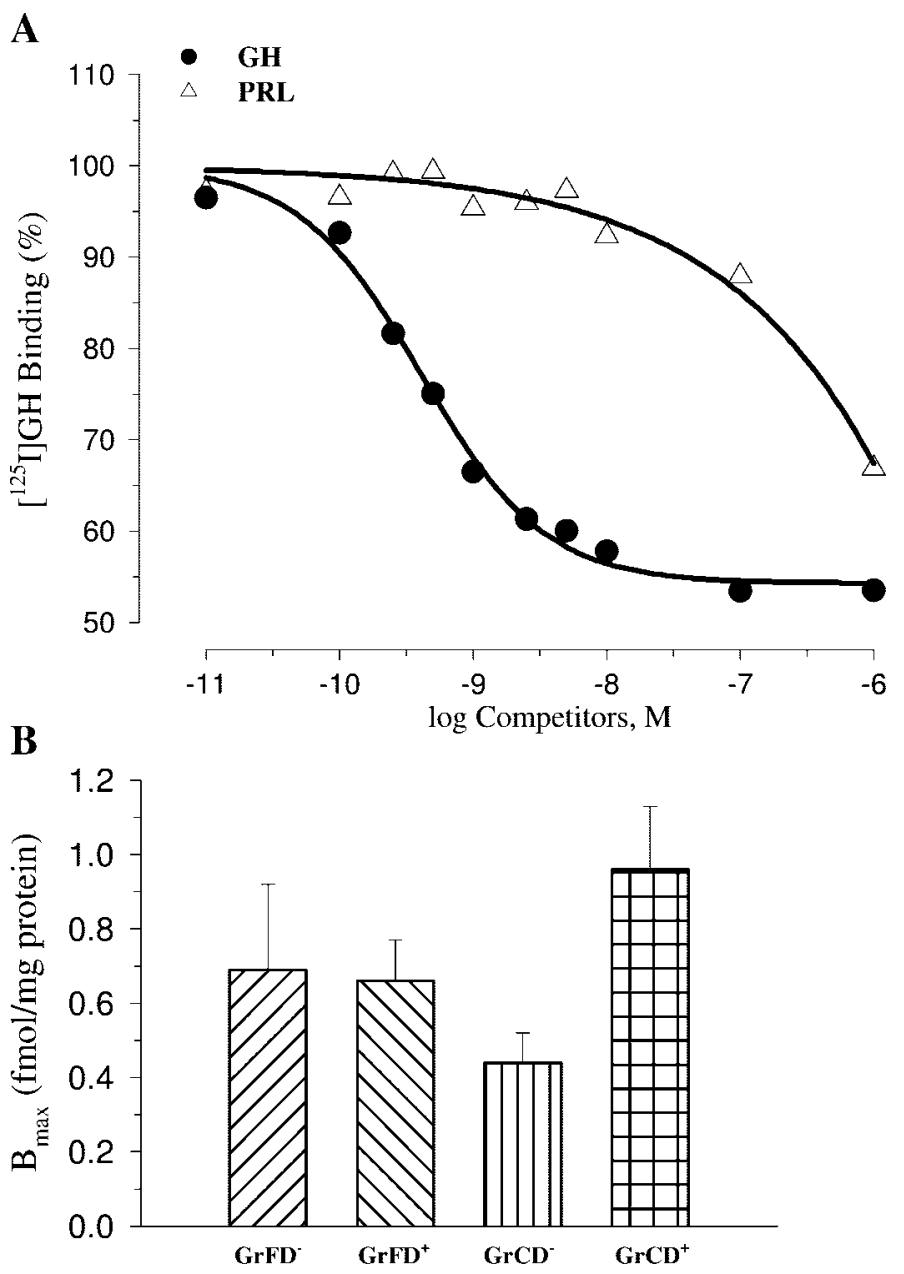

Fig. 4. ${ }^{125} \mathrm{I}$-labeled $\mathrm{GH}$ binding to $4 \mathrm{mg}$ of pooled membrane suspensions dependent on increasing concentrations of unlabeled $\mathrm{GH}(\bullet)$ and prolactin (PRL; $\triangle ; A$ ) and the number of ${ }^{125} \mathrm{I}-\mathrm{GH}$ binding sites in the liver of neonatal calves fed formula or colostrum without Dexa injections $\left(\mathrm{GrFD}^{-}\right.$and $\left.\mathrm{GrCD}^{-}\right)$and with Dexa injections $\left(\mathrm{GrFD}^{+}\right.$and $\left.\mathrm{GrCD}^{+}\right)$on day 5 of life $(B)$.

trations in Dexa-treated calves possibly resulted from elevated IGF-I concentrations because of negative feedback mechanisms of IGF-I on pituitary GH secretion (38). We have demonstrated a negative feedback mechanism in neonatal calves resulting from Long-R3IGF-I (20).

Hepatic GHR mRNA concentrations (especially the GHR 1A variant) and GHR binding in cattle are low at birth and increase with age, indicating ontogenetic maturation of the somatotropic axis $(1,7,31,43)$. GHRbinding studies revealed an almost fivefold increase of $\mathrm{B}_{\max }$ in bulls (450 kg body wt) compared with neonatal calves (Zbinden Y, Blum JW, and Hammon HM, unpublished data). In our study, colostrum intake did not influence GHR expression and GH binding in liver, but Dexa treatment increased hepatic GHR expression. The greatest GH binding was seen in calves fed colostrum and treated by Dexa. Glucocorticoids stimulated hepatic GHR mRNA in fetal sheep (30), neonatal pig (10), rabbit (24), and porcine (5) hepatocytes. Our findings indicate that Dexa, especially when accompa- nied by colostrum feeding, supports maturation of the somatotropic axis by stimulating hepatic GHR synthesis. Possibly, glucose might have caused the increase of GHR expression because glucose stimulated GHR mRNA in porcine hepatocytes (4) and because we found the highest glucose plasma concentrations in $\mathrm{GrCD}^{+}$ (Sauter SN, Blum JW, and Hammon HM, unpublished observation). Higher hepatic GH binding sites are an important basis for enhanced IGF-I responses to GH, and the response usually increases with age (8). The effects of Dexa treatment on GHR correspond to the view that parturition-associated mechanisms (such as high cortisol levels) are necessary for the postnatal increase of hepatic GH binding sites (6). Obviously, Dexa administration mimics the cortisol surge at birth and causes this postnatal hepatic GHR stimulation. Because the stimulation of GHR expression by Dexa was observed in both feeding groups but stimulation of GH binding by Dexa was only noticed in colostrum-fed calves, feeding of colostrum may regulate posttranscriptional GHR synthesis in Dexa-treated calves.

Feeding and Dexa effects on IGF-I expression and plasma concentrations. Although IGF-I plasma concentrations were numerically higher in colostrum-fed than in formula-fed calves and concentrations of hepatic IGF-I mRNA tended to increase in $\mathrm{GrCD}^{-}$compared with $\mathrm{GrFD}^{-}$, colostrum effects on neonatal IGF-I levels were not significant in the present study. These findings are contrary to our previous results $(13,20)$, but calves of those studies differed in age of the calves and/or feeding protocol.

Treatment with Dexa increased IGF-I plasma concentrations in this study, although glucocorticoids are known to inhibit postnatal growth in association with reduced IGF-I plasma concentrations $(9,48,49)$. However, our data correspond to findings in neonatal pigs (10) and growing bulls (43) treated with Dexa. However, Coxam et al. (15) did not find an effect of cortisol on plasma IGF-I concentrations in calves, and Dexa decreased plasma IGF-I concentrations in cows and finishing calves $(2,33)$. Therefore, effects of glucocorticoids on IGF-I plasma concentrations are variable and may depend on treatment-dose (34) and age (9). In any case, plasma IGF-I concentrations increase during postnatal development in cattle $(7,28,44)$. Therefore, elevated IGF-I concentrations in Dexa-treated calves, lower GH-to-IGF-I ratios in Dexa-treated calves, and the trend of lower GH-to-IGF-I ratios in colostrum-fed than in formula-fed calves indicate enhanced maturation of the somatotropic axis, as defined by Gluckman et al. (19).

Increased IGF-I plasma concentrations in Dexatreated calves might result from different clearance rates of IGF-I. Our study has demonstrated reduced plasma concentrations of IGFBP-1 and -2 in Dexatreated calves. These binding proteins are able to leave the blood circulation together with IGF-I. Because we found no differences in plasma concentrations of IGFBP-3, which (together with its acid-labile subunit) retains most IGF-I in circulation (25), and because the ratios of small IGFBPs to IGFBP-3 were lower in 
Dexa-treated calves, clearance of IGF-I from the circulation might have been reduced in Dexa-treated calves. Furthermore, insulin, which was elevated in Dexatreated calves (Sauter SN, Blum JW, and Hammon HM, unpublished observation) and enhances plasma IGF-I concentrations in cows (35), might have caused increased plasma IGF-I concentrations.

Hepatic production of IGF-I mainly determines circulating IGF-I concentrations $(9,13,25)$. Hepatic IGF-I expression increased after Dexa treatment in $\mathrm{GrFD}^{+}$ but decreased in $\mathrm{GrCD}^{+}$. Thus, in formula-fed calves, there was a positive association of IGF-I mRNA concentrations with IGF-I plasma concentrations, whereas there was a negative association in colostrumfed calves. An inverse behavior of IGF-I plasma concentrations and hepatic expression was also seen in neonatal Dexa-treated and colostrum-fed pigs (10). Different Dexa effects on IGF-I expression in formula- and colostrum-fed calves were surprising, because we have previously shown a significant relationship between hepatic IGF-I mRNA and plasma concentrations in 8-day-old calves (13). One could speculate that colostral IGF-I was intestinally absorbed and that Dexa treatment might have stimulated the absorption of colostral IGF-I, thus resulting in reduced hepatic IGF-I expression in colostrum-fed calves because of feedback inhibition $(20,38)$. However, there was no evidence for increased absorption of macromolecules like IgG in Dexa-treated calves (Sauter SN, Blum JW, and Hammon HM, unpublished observation), and we could not demonstrate significant absorption of IGF-I in neonatal calves $(20,50)$, although receptors for IGF-I are present in intestinal mucosa $(18,22)$. Different feeding may influence hepatic IGF-I mRNA stability after Dexa treatment and may regulate IGF-I production at the posttranscriptional level. Dexa depressed hepatic IGF-I mRNA levels in rats but increased IGF-I plasma concentrations in a dose-dependent manner (32). Interestingly, the hepatic IGF-II mRNA responses to feeding and Dexa treatment were comparable to IGF-I mRNA responses, pointing at similar regulatory mechanisms for hepatic IGF-I and IGF-II mRNA.

Feeding and Dexa effects on IGFBPs. Biological effects of IGF-I and IGF-II greatly depend on the presence of IGFBPs. Plasma concentrations of IGFBP-1 and -2 are high during fetal development and decrease after birth, whereas IGFBP-3, which (together with an acid-labile subunit) binds most of the IGF-I in blood, increases in blood after birth $(7,12,27,41)$. These patterns were also shown in calves (46). Plasma concentrations of IGFBP-1 and - 2 were reduced by Dexa treatment in the present study. Effects of glucocorticoids on IGFBP-1 plasma concentrations are variable; inhibitory and stimulatory effects are reported $(12,41)$. On the other hand, glucocorticoids consistently depress IGFBP-2 plasma concentrations $(12,27,41)$. Because insulin (Sauter SN, Blum JW, and Hammon HM, unpublished observation) and IGF-I plasma concentrations were elevated in Dexa-treated calves and both factors depress IGFBP-1 levels $(12,29)$, insulin and/or IGF-I may have caused the reduction of IGFBP-1 plasma concentrations in Dexa-treated calves. We did not measure hepatic IGFBP-1 gene expression in this study, but plasma concentrations of IGFBP-1 were regulated directly at the transcriptional level (12), and insulin overcame stimulatory effects of glucocorticoids on hepatic IGFBP-1 mRNA levels $(37,39)$. Furthermore, insulin suppressed IGFBP-2 plasma concentrations in cows (35), which is in accord with the present study. However, Dexa treatment did not influence hepatic expression of IGFBP-2, indicating that it did not regulate IGFBP-2 at the transcriptional level.

In addition, plasma IGFBP-2 concentrations in neonatal calves are regulated by the amount and time point of colostrum intake $(20,23)$. In our study, decreased IGFBP-2 plasma concentrations in colostrumfed calves were associated with reduced hepatic IGFBP-2 mRNA levels. Because nutrient intake was the same in formula- and colostrum-fed calves, other factors than nutrient density were responsible for reduced IGFBP-2 levels. Overall, decreasing levels of IGFBP-1 and IGFBP-2 induced by Dexa treatment and/or colostrum feeding in the present study support the hypothesis of an accelerated maturation of the somatotropic axis, as seen in postnatal development (7).

Furthermore, we found reduced hepatic IGFBP-3 mRNA levels after colostrum feeding, but this was not associated with reduced plasma concentrations. Concentrations of IGFBP-3 mRNA did not go along with hepatic IGF-I mRNA. Because effects of GH on the hepatic IGF system were weak, expression of IGFBP-3 was likely not regulated by GH and IGF-I as it is in the case of growing and adult animals $(7,12,41)$. Previous findings support lacking colostral effects on IGFBP-3 plasma concentrations (20). Surprisingly, hepatic expression and plasma concentrations of IGFBP-3 were not affected by Dexa treatment. We expected increased IGFBP-3 concentrations in Dexa-treated calves, because IGF-I and insulin were elevated and are known to stimulate IGFBP-3 production $(12,27)$. However, glucocorticoids reduced IGFBP-3 plasma concentrations in finishing calves (2), and Dexa did not influence hepatic IGFBP-3 mRNA in neonatal pigs (10). Therefore, IGFBP-3 levels in neonatal calves do not support the view of an accelerated maturation of the somatotropic axis by colostrum feeding or Dexa treatment.

In conclusion, the ratios of GH to IGF-I plasma concentrations in the present study were reduced by Dexa treatment and by colostrum feeding. Because a low GH-to-IGF-I ratio mirrors maturation of the somatotropic axis in neonates (19), both colostrum intake and Dexa treatment promoted maturation of the GHIGF-I axis, particularly if they were combined. Variable hepatic IGF-I mRNA responses after Dexa treatment depended on different feeding, indicating differences in IGF-I regulation. The higher number of GHR binding in colostrum-fed and Dexa-treated calves might have induced greater hepatic GH sensitivity and confirms the view of an accelerated maturation of the somatotropic axis. Furthermore, because nutrient intake was the same for all calves in the present study, 
Dexa effects on the GH-IGF-I system were not influenced by variable nutrient intake.

We thank Y. Aeby, J. Sturny, and their staff at the Swiss Federal Research Station for Animal Production, Posieux, Switzerland, for putting the calves at our disposal, and E. Husman (UFA AG, Sursee, Switzerland) for helping us develop the milk-based formula.

This work was presented as part of a thesis of S. N. Sauter at the Faculty of Veterinary Medicine, University of Berne, 2002.

\section{DISCLOSURES}

This study was supported by Swiss National Science Foundation Grant No. 32-59311.99.

\section{REFERENCES}

1. Badinga L, Collier RJ, Thatcher WW, Wilcox CJ, Head HH, and Bazer FW. Ontogeny of hepatic bovine growth hormone receptors in cattle. J Anim Sci 69: 1925-1934, 1991.

2. Bertozzi C, Protetelle D, Massart S, Prandi A, Darras V, Room G, Tassinari M, Vleurick L, Parmentier I, Haezebroeck V, Decuypere E, Burny A, and Renaville R. Dexamethasone ester treatment alters insulin-like growth factor-I, its binding proteins and thyroid status in finishing calves. Can $J$ Anim Sci 80: 329-335, 2000.

3. Blum JW and Baumrucker CR. Colostral and milk insulinlike growth factors and related substances: mammary gland and neonatal (intestinal and systemic) targets. Domest Anim Endocrinol 23: 101-110, 2002.

4. Brameld JM, Gilmour RS, and Buttery PJ. Glucose and amino acids interact with hormones to control expression of insulin-like growth factor-I and growth hormone receptor mRNA in cultured pig hepatocytes. J Nutr 129: 1298-1306, 1999.

5. Brameld JM, Weller PA, Saunders JC, Buttery PJ, and Gilmour RS. Hormonal control of insulin-like growth factor-I and growth hormone receptor mRNA expression by porcine hepatocytes in culture. J Endocrinol 146: 239-245, 1995.

6. Breier BH, Ambler GR, Sauerwein H, Surus A, and Gluckman PD. The induction of hepatic somatotrophic receptors after birth in sheep is dependent on parturition-associated mechanisms. J Endocrinol 141: 101-108, 1994.

7. Breier BH, Oliver MH, and Gallaher BW. Regulation of growth and metabolism during postnatal development. In: $R u$ minant Physiology: Digestion, Metabolism, Growth and Reproduction, edited by Cronjé PB. New York: CABI, 2000, p. 187204.

8. Breier BH and Sauerwein H. Regulation of growth in ruminants by the somatotropic axis. In: Ruminant Physiology: Digestion, Metabolism, Growth and Reproduction, edited by Engelhardt WV, Leonhard-Marek S, Breves G, and Giesecke D. Stuttgart, Germany: Verlag, 1995, p. 451-474.

9. Butler AA and LeRoith D. Control of growth by the somatotropic axis: growth hormone and the insulin-like growth factors have related and independent roles. Annu Rev Physiol 63: 141164, 2001.

10. Carroll JA. Dexamethasone treatment at birth enhances neonatal growth in swine. Domest Anim Endocrinol 21: 97-109, 2001.

11. Carroll JA, Daniel JA, Keisler DH, and Matteri RL. Postnatal function of the somatotrophic axis in pigs born naturally or by caesarian section. Domest Anim Endorinol 19: 39-52, 2000.

12. Clemmons DR. Insulin-like growth factor binding proteins and their role in controlling IGF actions. Cytokine Growth Factor Rev 8: 45-62, 1997.

13. Cordano P, Hammon HM, Morel C, Zurbriggen A, and Blum JW. mRNA of insulin-like growth factor (IGF) quantification and presence of IGF binding proteins, and receptors for growth hormone, IGF-I and insulin, determined by reverse transcribed polymerase chain reaction, in the liver of growing and mature male cattle. Domest Anim Endocrinol 19: 191-208, 2000.

14. Coxam V, Davicco MJ, Dardillat C, Robelin J, Lefaivre J, Opmeer F, and Barlet JP. Regulation of growth hormone release in fetal calves. Biol Neonate 54: 160-168, 1988.
15. Coxam V, Davicco MJ, Durand D, Bauchart D, Opmeer F, and Barlet JP. Steroid hormone may modulate hepatic somatomedin C production in newborn calves. Biol Neonate 58: 16-23, 1990.

16. Fowden AL. Endocrine regulation of fetal growth. Reprod Fertil Dev 7: 351-363, 1995.

17. Fowden A L, Szemere J, Hughes P, Gilmour PS, and Forhead AJ. The effects of cortisol on the growth rate of the sheep fetus during late gestation. J Endocrinol 151: 97-105, 1996.

18. Georgiev IP, Georgieva TM, Pfaffl M, Hammon HM, and Blum JW. Insulin-like growth factor and insulin receptors in intestinal mucosa of neonatal calves. J Endocrinol 176: 121-132, 2003.

19. Gluckman P D, Sizonenko SV, and Bassett NS. The transition from fetus to neonate: an endocrine perspective. Acta Paediatr Suppl 428: 7-11, 1999.

20. Hammon $\mathbf{H}$ and Blum JW. The somatotropic axis in neonatal calves can be modulated by nutrition, growth hormone, and Long-R3-IGF-I. Am J Physiol Endocrinol Metab 273: E130E138, 1997.

21. Hammon $\mathbf{H}$ and Blum JW. Metabolic and endocrine traits of neonatal calves are influenced by feeding colostrum for different durations or only milk replacer. J Nutr 128: 624-632, 1998.

22. Hammon HM and Blum JW. Feeding different amounts of colostrum or only milk replacer modify receptors of intestinal insulin-like growth factors and insulin in neonatal calves. Domest Anim Endocrinol 22: 155-168, 2002.

23. Hammon HM, Zanker IA, and Blum JW. Delayed colostrum feeding affects IGF-I and insulin plasma concentrations in neonatal calves. J Dairy Sci 83: 85-92, 2000.

24. Heinrichs C, Yanovski JA, Roth AH, Yu YM, Domené HM, Yano K, Cutler B Jr, and Baron J. Dexamethasone increases growth hormone receptor messenger ribonucleic acid levels in liver and growth plate. Endocrinology 135: 1113-1118, 1994.

25. Jones JI and Clemmons DR. Insulin-like growth factors and their binding proteins: biological action. Endocr Rev 16: 3-34, 1995.

26. Kaufhold JN, Hammon HM, Bruckmaier RM, Breier BH, and Blum JW. Postprandial metabolism and endocrine status in veal calves fed at different feeding frequencies. J Dairy Sci 83: 2480-2490, 2000.

27. Kelley KM, Oh Y, Gargosky SE, Gucev Z, Matsumoto T, Hwa V, Ng L, Simpson DM, and Rosenfeld RG. Insulin-like growth factor-binding proteins (IGFBPs) and their regulatory dynamics. Int J Biochem Cell Biol 28: 619-637, 1996.

28. Kerr DE, Laarveld B, Fehr MI, and Manns JG. Profiles of serum IGF-I concentrations in calves from birth to eighteen months of age and in cows throughout the lactation cycle. Can $J$ Anim Sci 71: 695-705, 1991.

29. Lee PD, Suwanichkul A, DePaolis LA, Snuggs MB, Morris SL, and Powel DR. Insulin-like growth factor (IGF) suppression of IGFBP-1 production: evidence for mediation by the type I IGF receptor. Regul Pept 48: 199-206, 1993.

30. Li J, Owens JA, Owens PC, Saunders JC, Fowden AL, and Gilmour RS. The ontogeny of hepatic growth hormone receptor and insulin-like growth factor 1 gene expression in the sheep during late gestation: developmental regulation by cortisol. Endocrinology 137: 1650-1657, 1996.

31. Lucy MC, Boyd CK, Koenigsfeld AT, and Okamura CS. Expression of somatotropin receptor messenger ribonucleic acid in bovine tissues. J Dairy Sci 81: 1889-1895, 1998.

32. Luo J and Murphy LJ. Dexamethasone inhibits growth hormone induction of insulin-like growth factor-I (IGF-I) messenger ribonucleic acid (mRNA) in hypophysectomized rats and reduced IGF-I mRNA abundance in the intact rat. Endocrinology 125: 165-171, 1989.

33. Marciel SM, Chamberlain CS, Wettemann RP, and Spicer LJ. Dexamethasone influences endocrine and ovarian function in dairy cattle. J Dairy Sci 84: 1998-2009, 2001.

34. McCusker RH. Controlling insulin-like growth factor activity and the modulation of insulin-like growth factor binding protein and receptor binding. J Dairy Sci 81: 1790-1800, 1998. 
35. McGuire MA, Dwyer DA, Harrell RJ, and Bauman DE. Insulin regulates circulating insulin-like growth factors and some of their binding proteins in lactating cows. Am J Physiol Endocrinol Metab 269: E723-E730, 1995.

36. Merriam GR and Wachter KW. Algorithms for the study of episodic hormone secretion. Am J Physiol Endocrinol Metab 243: E310-E318, 1982.

37. Miura Y, Higashi Y, Kato H, Takahashi SI, and Noguchi T. Effects of dexamethasone on the production of insulin-like growth factor-I and insulin-like growth factor binding proteins in primary cultures of rat hepatocytes. Biosci Biotech Biochem 56: 1396-1400, 1992.

38. Müller EE, Locatelli V, and Cocchi D. Neuroendocrine control of growth hormone secretion. Physiol Rev 79: 511-607, 1999.

39. Orlowski CC, Ooi GT, Brown DR, Yang YW, Tseng LY, and Rechler MM. Insulin rapidly inhibits insulin-like growth factor-binding protein-1 gene expression in H4-II-E rat hepatoma cells. Mol Endocrinol 5: 1180-1187, 1991.

40. Pfaff MW, Georgieva TM, Georgiev IP, Ontsouka E, Hageleit M, and Blum JW. Real-time RT-PCR quantification of insulin-like growth factor (IGF)-1, IGF-1 receptor, IGF-2, IGF-2 receptor, insulin receptor, growth hormone receptor, IGF-binding proteins 1,2 and 3 in the bovine species. Domest Anim Endocrinol 22: 91-102, 2002.

41. Rajaram S, Baylink DJ, and Mohan S. Insulin-like growth factor-binding proteins in serum and other biological fluids: regulation and functions. Endocr Rev 18: 801-831, 1997.
42. Rauprich ABE, Hammon HM, and Blum JW. Effects of feeding colostrum and a formula with nutrient contents as colostrum on metabolic and endocrine traits in neonatal calves. Biol Neonate 78: 53-64, 2000.

43. Renaville R, Hammadi M, and Portetelle D. Role of the somatotropic axis in the mammalian metabolism. Domest Anim Endocrinol 23: 351-360, 2002.

44. Ronge $\mathbf{H}$ and Blum J. Insulin-like growth factor I during growth in bulls. Reprod Nutr Dev 29: 105-111, 1989.

45. SAS Institute. SAS Users' Guide: Statistics. Cary, NC: SAS Institute, 1994.

46. Skaar TC, Baumrucker CR, Deaver DR, and Blum JW. Diet effects and ontogeny of alterations of circulating insulin-like growth factor binding proteins in newborn dairy calves. J Anim Sci 72: 421-427, 1994 .

47. Smith JM, Van Amburgh ME, Díaz MC, Lucy MC, and Bauman DE. Effects of nutrient intake on the development of the somatotropic axis and its responsiveness to $\mathrm{GH}$ in Holstein bull calves. J Anim Sci 80: 1528-1537, 2002.

48. Spencer GSG. Hormonal systems regulating growth. Livest Prod Sci 12: 31-46, 1985.

49. Unterman TG and Phillips LS. Glucocorticoid effects on somatomedins and somatomedin inhibitors. J Clin Endocrinol Metab 61: 618-626, 1985.

50. Vacher PY, Bestetti G, and Blum JW. Insulin-like growth factor I absorption in the jejunum of neonatal calves. Biol Neonate 68: 354-367, 1995.

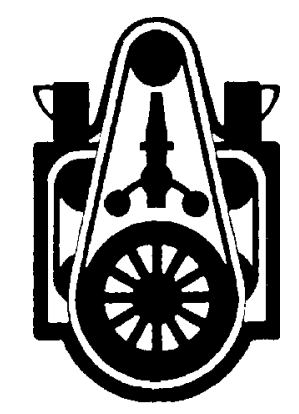

